\title{
Оцінка ефективності застосування плазмаферезу в комплексній терапіі гострого некротичного панкреатиту
}

\author{
К. Є. Іщейкін ${ }^{1}$, Д. І. Гребенюк ${ }^{2}$, О. М. Зацерковна², І. В. Таран ${ }^{2}$, К. М. Паньків² \\ ${ }^{1}$ Українська медична стоматологічна академія, м. Полтава, \\ ${ }^{2}$ Вінницький національний медичний університет імені М. І. Пирогова

\section{Estimation of efficacy of the plasmapheresis application in complex therapy of an acute necrotic pancreatitis}

\author{
K. Ye. Ishcheikin ${ }^{1}$, D. I. Grebeniuk ${ }^{2}$, O. M. Zatserkovna ${ }^{2}$, I. V. Taran ${ }^{2}$, K. M. Pankiv ${ }^{2}$ \\ ${ }^{1}$ Ukrainian Medical Stomatological Academy, Poltava, \\ ${ }^{2}$ Pyrogov National Medical University, Vinnytsya
}

\section{Рeферат}

Мета. Вивчити вплив плазмаферезу (ПФ) на лабораторні показники інтоксикації та запального процесу у пацієнтів 3 гострим некротичним панкреатитом (ГНП).

Матеріали і методи. До дослідження залучено 73 пацієнти з ГНП. Контрольну групу склали 27 пацієнтів, які отримували інтенсивну медикаментозну терапію. До основної групи включили 46 пацієнтів, яким стандартну інтенсивну терапію доповнили ПФ. Крім рутинних, вивчали показники інтоксикації та маркери запалення.

Результати. У пацієнтів основної групи показники інтоксикації та запалення вже після першого сеансу ПФ були достовірно нижчими за аналогічні показники у пацієнтів контрольної групи. Щодо частини пацієнтів, у яких зазначені показники наближалися до аналогічних показників у здорових людей, було прийнято рішення обмежитися лише одним сеансом ПФ. Решті паціентів провели два, а окремим - навіть три сеанси ПФ. Після повторних сеансів ПФ показники інтоксикації та запалення у пацієнтів основної групи достовірно відрізнялися не лише від аналогічних показників у пацієнтів контрольної групи, а й від показників у пацієнтів, яким було проведено лише один сеанс екстракорпоральної детоксикації.

Висновки. ПФ зменшує клінічні прояви панкреатиту, а також знижує лабораторні показники інтоксикації та запального процесу.

Ключові слова: гострий некротичний панкреатит; інтоксикація; плазмаферез.

Abstract

Objective. To study up the impact of plasmapheresis (PPH) on laboratory indices of intoxication and inflammatory process in patients, suffering an acute necrotic pancreatitis (ANP).

Materials and methods. In the investigation 73 patients, suffering an ANP, were included. The Control Group have consisted of 27 patients, who obtained intensive medicinal therapy. The Main Group have included 46 patients, in whom a standard intensive therapy was added by PPH. Besides conventional tests, the indices of intoxication and markers of inflammation were studied. Results. In patients of the Main Group the indices of intoxication and inflammation already after first s ance of PPH were trustworthily lower, than the analogous indices in patients of a Control Group. For those patients, in whom the indices noted have approximated the analogous indices of healthy persons, the decision was accepted to do the only one s ance of PPH. While in the other patients were conducted two and in some - even three s ances of PPH. After secondary s ances of PPH the indices of intoxication and inflammation in patients of the Main Group have been trustworthily differed from not only analogous indices in patients of the Control Group, but as well as from the indices in patients, to whom the only one s ance of extracorporeal detoxication was conducted.

Conclusion. PPH reduces clinical signs of pancreatitis, as well as the laboratory indices of intoxication and inflammatory process. Keywords: acute necrotic pancreatitis; intoxication; plasmapheresis.

Гострий некротичний панкреатит (ГНП), який є частою патологією в сучасній хірургічній практиці (30 - 40 спостережень на 100000 населення за рік) [1 - 3], характеризується тяжким перебігом та високою смертністю. Прогноз значно погіршується у разі інфікування панкреонекрозу. В останні роки в інтенсивній терапії деструктивного панкреатиту особливо широко застосовують методи екстракорпоральної детоксикації: гемо- та лімфосорбцію, обмінний ПФ [4 - 6].

Враховуючи патогенетичні особливості ГНП, актуальним є застосування в його комплексному лікуванні ПФ, який, крім безпосереднього еферентного ефекту (звільнення організму від токсичних речовин), ще й позитивно впливає на саму підшлункову залозу і особливо на уражену парапанкреатичну клітковину.

Мета дослідження: вивчити вплив ПФ на лабораторні показники інтоксикації та запального процесу у пацієнтів з ГНП.

\section{Матеріали і методи дослідження}

До дослідження залучені 73 пацієнти з ГНП, яким проводили лікування в клініці кафедри ендоскопічної та серце- 
во-судинної хірургії Вінницького національного медичного університету імені М. І. Пирогова на базі відділення абдомінальної хірургії та відділення анестезіології та інтенсивної терапії Вінницької обласної клінічної лікарні імені М. І. Пирогова. Вік пацієнтів коливався від 19 до 60 років, середній вік становив $(42,6 \pm 1,4)$ року. Чоловіків було 45 (61,6\%), жінок - 28 (38,4\%).

Діагноз захворювання встановлювали згідно з класифікацією Атланта-2012. Тяжкість стану хворих, яку визначали за шкалою АРАCНЕ II була оцінена у 8 балів і вище.

Пацієнтів випадковим чином розподілили на дві групи. Контрольну групу склали 27 пацієнтів, які отримували стандартну інтенсивну терапію, що включала раціональну антибіотикотерапію, відновлення об'єму циркулюючої крові, корекцію кислотно-основного та водноелектролітного обміну, дезінтоксикаційну, антиферментну, антисекреторну терапію, метаболічне забезпечення. До основної групи включили 46 пацієнтів, яким стандартну інтенсивну терапію доповнили екстракорпоральною детоксикацією.

Лабораторна та інструментальна діагностика проведена також 30 умовно здоровим людям з метою визначення нормальних значень аналогічних показників.

Як метод екстракорпоральної детоксикації застосовували обмінний ПФ, використовуючи центрифугу РС6 і полімерні контейнери «Гемакон 500/300». Починали проводити ПФ у середньому через $(2,46 \pm 1,3)$ доби після госпіталізації пацієнта у відділення інтенсивної терапії. Плазму заміщали шляхом інфузії розчинів поліелектролітів, синтетичних амінокислот, реополіглюкіну, 5 - 10\% розчинів альбуміну.

У залежності від тяжкості стану хворого сеанс ПФ включав 1 - 3 цикли ексфузії крові з видаленням 300 - 1500 мл плазми та поверненням еритроцитарної маси. Протягом лікування пацієнти основної групи отримали всього 73 сеанси ПФ (у середньому 2,8 сеанса на одного пацієнта).

Якість лікування оцінювали шляхом рутинної реєстрації клініко-біохімічних показників, а також показників інтоксикації - вмісту молекул середньої маси (МСМ), лейкоцитарного індексу інтоксикації (ЛІІ), рівнів малонового діальдегіду (МДА), каталази (КТ), циркулюючих імунних комплексів (ЦІК).

Крім того, нами досліджено такі маркери активності запального процесу, як фактор некрозу пухлини - $\alpha$ (tumor necrosis factor $-\alpha-\mathrm{TNF}-\alpha$ ) та інтерлейкін -8 (IL-8).

Одержані дані опрацьовували за допомогою пакета статистичних програм SPSS 20.0 for Windows.

\section{Результати}

У 17 хворих спостерігали повернення симптомів інтоксикації на наступну добу після проведення ПФ, що пов'язано з дренуючим ефектом ПФ, інтенсивнішою мікролімфоциркуляцією та «проривом» токсичних речовин із деблокованих елементів інтерстицію. Відповідно виникла потреба в повторних сеансах ПФ, яких було проведено від одного до трьох з інтервалом 24 - 48 год.

У 23 хворих констатували позитивний ефект після другого сеансу ПФ, про що свідчило покращення їх клінічного стану: Зникли явища делірію, зменшилися прояви парезу кишечника, знизилися температура тіла, частота пульсу, ЛІІ, а найбільш ефективно - концентрація білірубіну та $\alpha$-амілази (табл. 1 ).

Після сеансу ПФ, проведеного на фоні стандартної інтенсивної терапії, з 24 хворих основної групи, які мали збільшення в крові рівня $\alpha$-амілази, у 10 хворих уже на 3 - 4-ту добу лікування цей показник значно покращився

\begin{tabular}{|c|c|c|c|c|}
\hline \multirow[t]{2}{*}{ Показник } & \multicolumn{2}{|c|}{$\begin{array}{c}\text { Етапи дослідження } \\
(\bar{x} \pm m)\end{array}$} & \multirow{2}{*}{$\begin{array}{c}\text { Динаміка зниження, } \\
\%\end{array}$} & \multirow[t]{2}{*}{$\mathrm{p}<$} \\
\hline & до ПФ & після ПФ & & \\
\hline Температура тіла, ${ }^{\circ} \mathrm{C}$ & $38,5 \pm 0,27$ & $37,4 \pm 0,34$ & 3,1 & 0,01 \\
\hline Частота пульсу, за 1 хв & $108,8 \pm 1,96$ & $94,5 \pm 2,12$ & 13,2 & 0,001 \\
\hline Білірубін, мкмоль/мл & $52,4 \pm 1,6$ & $29,1 \pm 0,9$ & 44,5 & 0,001 \\
\hline Сечовина, ммоль/л & $8,30 \pm 0,41$ & $6,74 \pm 0,38$ & 18,8 & 0,01 \\
\hline Креатинін, ммоль/л & $0,096 \pm 0,001$ & $0,081 \pm 0,001$ & 15,6 & 0,001 \\
\hline$\alpha$-амілаза, Од/л & $54,8 \pm 1,2$ & $28,1 \pm 2,04$ & 48,7 & 0,001 \\
\hline
\end{tabular}

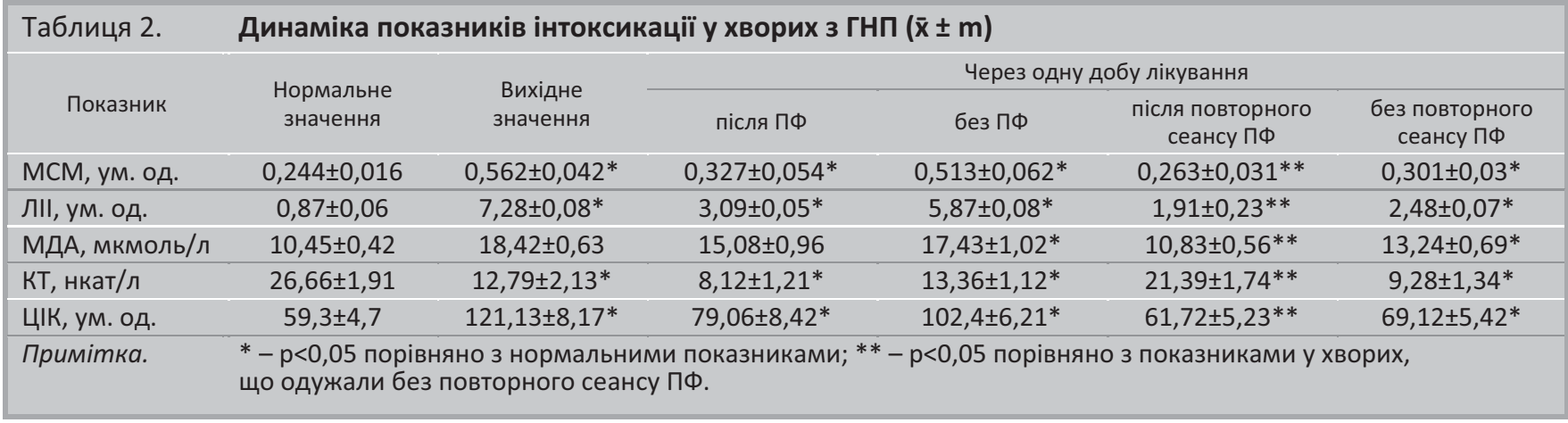




\begin{tabular}{|c|c|c|c|c|c|c|}
\hline \multirow[b]{2}{*}{ Показник } & \multirow{2}{*}{$\begin{array}{l}\text { Нормальне } \\
\text { значення }\end{array}$} & \multirow{2}{*}{$\begin{array}{c}\text { Вихідне } \\
\text { значення } \\
\text { до ПФ }\end{array}$} & \multicolumn{4}{|c|}{ Через одну добу лікування } \\
\hline & & & після ПФ & без ПФ & $\begin{array}{l}\text { після повторного } \\
\text { сеансу ПФ }\end{array}$ & $\begin{array}{l}\text { без повторного } \\
\text { сеансу ПФ }\end{array}$ \\
\hline TNF- $\alpha, п г / м л$ & $48,9 \pm 5,6$ & $65,2 \pm 7,8$ & $62,7 \pm 6,5$ & $64,3 \pm 5,6$ & $52,5 \pm 6,2$ & $59,3 \pm 7,3$ \\
\hline IL-8, пг/мл & $19,1 \pm 1,1$ & $224,1 \pm 10,3$ & $205,4 \pm 11,2$ & $220,5 \pm 9,8$ & $161,5 \pm 7,1$ & $212,4 \pm 13,2$ \\
\hline Примітка. & \multicolumn{6}{|c|}{$\begin{array}{l}\text { * - p < 0,05 порівняно з нормальними показниками; }{ }^{* *}-p<0,05 \text { порівняно з показниками у хворих, що одужали } \\
\text { без повторного сеансу ПФ. }\end{array}$} \\
\hline
\end{tabular}

та залишився стабільним. Із 14 хворих з деструктивними формами панкреатиту у 2 не спостерігали позитивної динаміки рівня $\alpha$-амілази, у 7 рівень $\alpha$-амілази знизився до 8-ї, у 5 - до 32-ї доби лікування.

Рівень МСМ у хворих перед першим сеансом ПФ був достовірно вищий $(\mathrm{p}<0,01)$ за аналогічний нормальний показник (табл. 2). Через одну добу після першого сеансу ПФ даний показник достовірно знизився $(\mathrm{p}<0,01)$ відносно його вихідного рівня. Натомість у пацієнтів, яким ПФ не проводили, рівень МСМ дещо знизився, проте недостовірно ( $>$ > 0,05). На цьому етапі дослідження за даним показником групи пацієнтів достовірно відрізнялися $(\mathrm{p}<0,01)$. Через одну добу після повторного сеансу ПФ рівень МСМ знизився ще більше і практично не відрізнявся від нормальних значень. У групі пацієнтів, яким ПФ не проводили, даний показник достовірно знизився $(\mathrm{p}<0,01)$, хоча й значно перевищував нормальні значення. Це можна пояснити позитивним впливом комплексної медикаментозної терапії. На цьому етапі дослідження за даним показником групи пацієнтів також достовірно відрізнялися $(\mathrm{p}<0,01)$.

Аналогічна тенденція простежувалася також і за даними аналізу динаміки показників ЛІІ, МДА та ЦІК. Щодо динаміки показників МДА, то вона дещо відрізнялася. Так, після першого сеансу ПФ рівень МДА знизився недостовірно ( $>$ > 0,05), після повторного сеансу ПФ даний показник був достовірно нижчий $(\mathrm{p}<0,01)$ за його вихідний рівень, практично не відрізнявся від нормальних значень (p > 0,05). У пацієнтів, яким повторного сеансу ПФ не проводили, рівень МДА також достовірно (p < 0,01) знизився, але значно перевищував нормальні значення, що можна пояснити позитивною дією комплексної медикаментозної терапії.

Шляхом аналізу динаміки маркерів запального процесу отримані такі дані (табл.3). Перед першим сеансом ПФ рівень TNF- $\alpha$ був достовірно вищий $(\mathrm{p}<0,01)$ за аналогічний нормальний показник. Через одну добу після першого сеансу даний показник достовірно знизився ( $\mathrm{p}<0,05$ ) відносно вихідного рівня. Натомість у пацієнтів, яким ПФ не проводили, рівень TNF- $\alpha$ знизився недостовірно (p > 0,05). Через 1 добу після повторного сеансу ПФ рівень TNF- $\alpha$ знизився ще більше. У пацієнтів, яким повторного сеансу ПФ не проводили, даний показник також достовірно ( $\mathrm{p}<0,05)$ знизився відносно вихідного рівня, але значно перевищував нормальні значення. Це можна пояснити позитивною дією комплексної медикаментозної терапії. На даному етапі дослідження за цим показником групи пацієнтів також достовірно відрізнялися (p < 0,01).

Аналогічна тенденція простежувалася і щодо динаміки показників IL-8.

\section{Обговорення}

ПФ як метод еферентної терапії набуває дедалі ширшого застосування в клінічній практиці. Порушення складу внутрішнього середовища, які багато в чому визначають тяжкість перебігу хвороби і навіть є основними чинниками несприятливих наслідків, незважаючи на використання найсучасніших медикаментозних засобів або хірургічних втручань, виникають через гострі запальні захворювання органів грудної та черевної порожнин, тяжкі травми й опіки, отруєння та інфекційні хвороби, коли розвивається синдром ендогенної інтоксикації з вторинним пригніченням системи імунного захисту, так званий імунний дистрес-синдром. У такій ситуації шляхом детоксикації з виведенням ендотоксинів та інших патологічних продуктів можна домогтися перелому перебігу захворювання.

За наявності ендогенної інтоксикації, зумовленої ГНП, яка є найважливішим чинником розвитку тяжких порушень гомеостазу та загрозливих для життя системних ускладнень, необхідна елімінація відповідних факторів панкреатичної аутоагресії із внутрішнього середовища організму. Наразі найбільш ефективним методом видалення токсинів із системного кровотоку є процедура екстракорпоральної детоксикації.

У пацієнтів, залучених нами до дослідження, показники інтоксикації та запалення вже після першого сеансу ПФ були достовірно нижчими за аналогічні показники у пацієнтів контрольної групи. 3 огляду на це щодо частини пацієнтів, у яких значення даних показників наближалися до значень аналогічних показників у здорових людей, було вирішено обмежитися лише одним сеансом ПФ. Решті пацієнтів провели два, а окремим - навіть три сеанси ПФ.

Після повторних сеансів ПФ значення показників інтоксикації та запалення у пацієнтів основної групи достовірно відрізнялися не лише від значень аналогічних показників у пацієнтів контрольної групи, а й від значень показників у пацієнтів, яким було проведено лише один сеанс екстракорпоральної детоксикаціі.

\section{Висновки}

ПФ як метод екстракорпоральної детоксикації покращує загальний стан пацієнтів із ГНП, про що свідчить зменшення клінічних проявів панкреатиту, а також зни- 
ження лабораторних показників інтоксикації (ЛІІ, рівнів МСМ, МДА, каталази, ЦІК) та маркерів запального процеcy $(\mathrm{TNF}-\alpha, \mathrm{IL}-8)$.

\section{Підтвердження}

Інформація про фінансування. Робота виконана без залучення додаткових джерел фінансування.

Інформація про внесок кожного учасника. К. $Є$. Іщейкін - концепція і дизайн дослідження; Д.І. Гребенюк - збір та опрацювання матеріалу, аналіз отриманих даних, написання тексту статті; О. М. Зацерковна - збір та опрацювання матеріалу, написання тексту статті; I. В. Таран аналіз отриманих даних; К. М. Паньків - збір та опрацювання матеріалу. Всі автори прочитали і схвалили остаточний варіант рукопису.

Етичне підтвердження. Всі процедури, застосовані до учасників цього дослідженнях, відповідали етичним стандартам інституційного та/або національного дослідницького комітету, а також Гельсінкської декларації 1964 року і ііі більш пізнім змінам або порівнянним етичним стандартам. Ця стаття не містить даних ніяких досліджень 3 тваринами, проведених будь-ким з авторів.

Конфлікт інтересів. Автори заявляють, що вони не мають конфлікту інтересів.

Згода на публікацію. Всі автори дали згоду на публікацію цього рукопису.

\section{References}

1. Chua TY, Walsh RM, Baker ME, Stevens T. Necrotizing pancreatitis: Diagnose, treat, consult. Cleve Clin J Med. 2017 Aug;84(8):639-648. / doi: 10.3949/ccjm.84a.16052.

2. Maheshwari R, Subramanian RM. Severe Acute Pancreatitis and Necrotizing Pancreatitis. Crit Care Clin. 2016 Apr;32(2):279-90. doi: 10.1016/j. ccc.2015.12.006.

3. Portelli M, Jones CD. Severe acute pancreatitis: pathogenesis, diagnosis and surgical management. Hepatobiliary Pancreat Dis Int. 2017 Apr;16(2):155-9. PMID: 28381378.

4. Hong B, Ling Z, Songmin H, Tao Z, Ruichao Y. Continuous venovenous hemofiltration and hemoperfusion in successful treatment of a patient with crush syndrome and acute pancreatitis. Ren Fail. 2012;34(3):3836. doi: 10.3109/0886022X.2011.647370.

5. Huang SP, Toh DE, Sue YM, Chen TH, Cheng SW, Cheng CY. Double filtration plasmapheresis in treatment of acute pancreatitis associated with severe hypertriglyceridemia: Three case reports. Medicine (Baltimore). 2018 Nov;97(44):e12987. doi: 10.1097/MD.0000000000012987.

6. Uyar S, Harmandar F, Kök M, Taş Z, Dolu S, Tokuç A, et al. Management of hypertriglyceridemia induced acute pancreatitis and therapeutic plasmapheresis: Report of nine cases and review of literature. Acta Gastroenterol Belg. 2017 Jan-Mar;80(1):71-4. PMID: 29364102. 